\title{
Do otters target the same fish species and sizes as anglers? A case study from a lowland trout stream (Czech Republic)
}

\author{
Roman Lyach* and Martin Čech \\ Institute for Environmental Studies, Faculty of Science, Charles University in Prague, Benátská 2, 12801 Prague, Czech Republic
}

Received 14 September 2016 / Accepted 7 March 2017

\begin{abstract}
Stocking of hatchery-reared fish into streams is a common practice in fisheries industry as it provides catches for recreational anglers and support for native fish populations. The Eurasian otter Lutra lutra is one of the most important freshwater piscivorous predators in Europe. Impact of otters on stocked fish is a source of conflict between fisheries industry and environmental protection. This study aimed to describe differences between otter diet and catches of anglers on a lowland trout stream with salmonid stocking. Otter diet was studied during winter, using spraint analysis. Fish dominated otter diet $85 \%$ of biomass). Gudgeon Gobio gobio was the most important otter prey ( $38 \%$ of biomass). Catches of otters and catches of anglers on the stream were significantly different. Otters mostly preyed upon small-growing fish species of medium or no angling value while anglers took large-growing fish species of medium and high angling value. Otters took fish with average weight of $10 \mathrm{~g}$ while anglers took fish with average weight of 290 g. Stocked salmonids made up $13 \%$ of estimated biomass in otter diet. Otters targeted significantly different fish species of different sizes than anglers did.
\end{abstract}

Keywords: Brown trout Salmo trutta m. fario / Fish losses / Fish predation / Hatchery-reared fish / Pharyngeal bones / Rainbow trout Oncorhynchus mykiss

\section{Introduction}

The Eurasian otter Lutra lutra is one of the most important fish-eating mammals in European freshwater ecosystems (Mason and Macdonald, 1986; Kruuk, 1995, 2006). Otter populations in Europe declined dramatically during the 20th century, mainly due to water pollution, poaching, increased road traffic, and habitat loss (Kranz, 2000), yet have begun to recover in the last 20-30 years (Kranz, 2000; Conroy and Chanin, 2002). With rising numbers of otters in the wild, their effect on fish stocks is being heatedly debated between anglers and fishermen on one side and environmentalists and the society itself on the other (Kruuk et al., 1991, 1993; Kranz, 2000; Adámek et al., 2003; Jacobsen, 2005; Václavíková et al., 2011). Fishermen claim that otters are significantly responsible for losses on farmed and stocked fish (Kloskowski, 2000; Adámek et al., 2003; Kortan et al., 2007), while environmentalists consider otters to be flagship species of aquatic ecosystems (Juhász et al., 2013), and the society considers otters to be highly charismatic and popular animals.

Although otters live in a large variety of watery habitats (Mason and Macdonald, 1986; Conroy and Chanin, 2002), smaller streams are especially important as migratory routes. They provide them with steady, sufficient, and reliable source of

\footnotetext{
* Corresponding author: roman. lyach@natur.cuni.cz
}

fish prey (Jurajda et al., 1996; Ludwig et al., 2002; Lanszki et al., 2009), especially in cold winters when water bodies freeze over (Lanszki et al., 2009; Sittenthaler et al., 2015). Otters are (to a certain extent) fish-eating specialists (Erlinge, 1969; Taastrom and Jacobsen, 1999; Copp and Roche, 2003), but within this category, they are opportunistic predators (Carss et al., 1990; Taastrom and Jacobsen, 1999; Lanszki et al., 2001; Geidezis, 2002). They usually take the most abundant and available fish prey (Jurajda et al., 1996; Chanin, 2003; Kortan et al., 2007), although they can be selective as well, for example by preferring younger age classes of large-growing pond fish (Kloskowski, 2000) or partially rejecting non-native species (Blanco-Garrido et al., 2008; Miranda et al., 2008). In freshwater ecosystems in moderate climate, otters usually prey upon smaller fish of no commercial value, with larger fish being taken only occasionally (Jurajda et al., 1996; Lanszki and Sallai, 2006; Lanszki and Széles, 2006, Lanszki et al., 2015).

Salmonid stocking is a common practice in fisheries management of trout streams (Larsen, 1972; Baer et al., 2007). The main goal is to increase the numbers of commercially attractive fish in the streams in order to increase the yield of recreational anglers. Large legal or almost-legal sized salmonids $(17-30 \mathrm{~cm}, 150-400 \mathrm{~g})$ are usually being stocked for this purpose (Rasmussen and Geertz-Hansen, 1998). Another goal is to support native wild fish populations and to re-establish extirpated fish populations by stocking smaller salmonids (10-15 cm, 10-30 g), mostly because fish stocked at 
older life have higher mortality than stocked fry (Naslund, 1992). Although otters show preference for slow-moving cyprinids during warmer months, they prey on salmonids as well (Mason and Macdonald, 1986; Taastrom and Jacobsen, 1999), especially during winter when the endothermic predator has higher advantage over its ectothermic prey (Ludwig et al., 2002), and when non-fish prey becomes less available (Kortan et al., 2007). Stocked salmonids have poorly developed antipredation behaviour (Maynard et al., 1995; Jacobsen, 2005) and reduced ability to capture prey and defend their feeding grounds (Bachman, 1984); therefore they are particularly vulnerable to predation (Aarestrup et al., 2005).

The goal of this study was to analyze otter diet in one winter season on a secondary trout lowland stream that is being stocked with salmonids, used by anglers, and being polluted from a cascade of upstream ponds. The stream is being used by one to three otters (based on tracking in snow). We hypothesized that otter catches would differ from catches of anglers since anglers select specific fish species and sizes while otters usually take the most abundant and available prey.

\section{Materials and methods}

\subsection{Study area}

The study was carried out on Chotýšanka stream (Fig. 1), a small lowland stream (45 km south-east from Prague, fishery no. 413 006, Chotýšanka 1, in the list of fisheries of the Czech Anglers Union) in Central Bohemia, Czech Republic, during winter 2005/2006. It is a left-hand tributary to the Blanice River on the 8th kilometre (Vltava River basin). It is $11.7 \mathrm{~km}$ long, meandering coefficient 1.15 , average width $4.44 \mathrm{~m}$, average annual flow of $0.68 \mathrm{~m}^{3} \mathrm{~s}^{-1}$ at the mouth, $690 \mathrm{~mm}$ annual rainfall by long-term measurement. Average air temperature in December 2005 was $-1.3{ }^{\circ} \mathrm{C}$; in January 2006 it was $-6^{\circ} \mathrm{C}$ in this area (Czech Hydrometeorological Institute, unpubl. data). The area has a temperate climate and an altitude of $320 \mathrm{~m}$ above sea level. It is located between pond Smikov $\left(49^{\circ} 43^{\prime} 32.2^{\prime \prime} \mathrm{N}, 14^{\circ} 49^{\prime} 53.0^{\prime \prime} \mathrm{E}\right)$ and the Blanice River $\left(49^{\circ} 45^{\prime} 34.0^{\prime \prime} \mathrm{N}, 14^{\circ} 54^{\prime} 52.6^{\prime \prime} \mathrm{E}\right)$, and covers an area of 5 ha. The stream is surrounded by meadows and forest, and is situated in a region with active soil erosions. The stream has two smaller tributaries on kilometre 5.5 and 7.

The stream is listed as trout water and is alpha/beta mesosaprobic. Discharge of warm and eutrophic water from the pond surface occurs frequently in the summer, increasing the water temperature under the pond. Dredging during autumnal (middle to late October 2005) fish harvest caused release of large portions of muddy water, polluted with organic compounds, that swept fish stocks downstream, making them migrate back upstream in order to recolonise the area. Since there is no other source of water pollution on the stream, the own flow gets cleaner downstream as it dilutes and thereby rids itself of the organic, muddy, and thermal pollution. Irregular summer discharges are causing occasional droughts (Poupě, unpubl. data). Those are especially relevant in the upstream section (Fig. 1) since there is no additional tributary or other consistent water source and fewer pools present in this stream section (own observation).

Salmonid stocking was conducted from September to November 2005 (Table 1). Fish were stocked on several spots

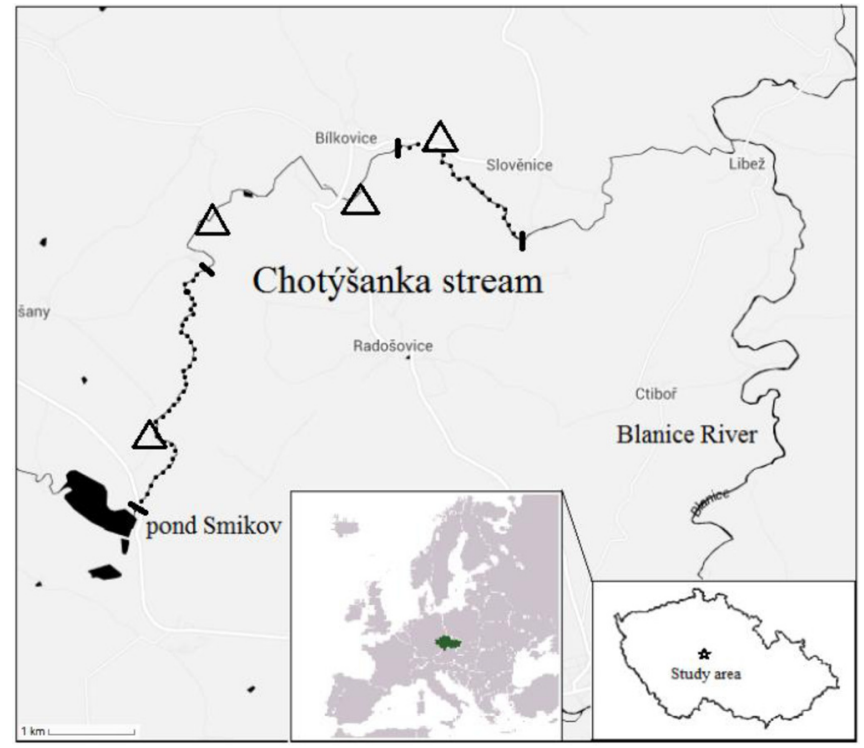

Fig. 1. Map of the study area: Chotýšanka stream (Central Bohemia, Czech Republic); the dotted line represents the stretches where spraints of Eurasian otter Lutra lutra were found and collected in winter 2005/2006 ( $\mathrm{km} \mathrm{3.0-5.5} \mathrm{and} \mathrm{7.5-11.7} \mathrm{from} \mathrm{the} \mathrm{confluence} \mathrm{with}$ the Blanice River); the full line represents section limits; the triangles represent spots where fish stocking occurred in September-November 2005.

Table 1. Fish stocking on Chotýšanka stream (Chotýšanka 1, fishery no. 413 006) in September-November 2005: species, fish species stocked; number, total number of stocked fish; biomass, total biomass of stocked fish $[\mathrm{kg}]$; length, individual fish length $[\mathrm{cm}]$; weight, individual fish weight $[\mathrm{g}]$.

\begin{tabular}{lllcc}
\hline Species & Number & Biomass & Length & Weight \\
\hline $\begin{array}{l}\text { Brown trout Salmo } \\
\text { trutta } \text { m. fario }\end{array}$ & 5000 & 100 & $8-15$ & $10-30$ \\
$\begin{array}{l}\text { Rainbow trout } \\
\text { Oncorhynchus mykiss }\end{array}$ & 480 & 120 & $25-35$ & $200-400$ \\
\hline
\end{tabular}

where the stream was accessible from the bank (Fig. 1). Stocked salmonids were reared in a hatchery on pellet food and had no prior experience with a natural habitat or a predator of any kind. All fish seemed to be in a good shape before stocking (Czech Anglers Union, unpubl. data). Statistics regarding catches of anglers are collected by Czech Anglers Union every year; it is mandatory for anglers to report all fish they remove from the stream.

In years 2005-2006, altogether 180 visits of 42 individual anglers occurred on the stream. Anglers caught and took away from the stream altogether 107 individual rainbow trout Oncorhynchus mykiss with total biomass of $31.6 \mathrm{~kg}$ (average fish weight $0.3 \mathrm{~kg}$ ), 9 individual brown trout Salmo trutta m. fario with total biomass of $2.3 \mathrm{~kg}$ (average fish weight $0.3 \mathrm{~kg}$ ), 283 individual European chub Squalius cephalus with total biomass of $49.3 \mathrm{~kg}$ (average fish weight $0.17 \mathrm{~kg}$ ), 2 individual 
Table 2. The number of spraints of Eurasian otter Lutra lutra collected on Chotýšanka stream (Chotýšanka 1, fishery no. 413 006) in winter 2005/2006: date, date of spraint collection; spraints, number of spraints collected; $n$, number of food items identified in spraints; $b$, estimated biomass of all food items identified in spraints [kg], Sec1, Section 1 (km 7.5-11.7); Sec2, Section 2 (km 3.0-5.5) (Fig. 1).

\begin{tabular}{|c|c|c|c|c|c|c|}
\hline Date & \multicolumn{2}{|c|}{ Spraints } & \multicolumn{2}{|c|}{$n$} & \multicolumn{2}{|c|}{$b$} \\
\hline 11 Dec 2005 & 92 & 61 & 547 & 319 & 6.12 & 4.13 \\
\hline 14 Jan 2006 & 82 & 44 & 430 & 299 & 5.20 & 3.25 \\
\hline Total & 174 & 105 & 977 & 618 & 11.32 & 7.38 \\
\hline
\end{tabular}

brook trout Salvelinus fontinalis with total biomass of $0.5 \mathrm{~kg}$ (average fish weight $0.25 \mathrm{~kg}$ ), one individual common carp Cyprinus carpio (weight $2.1 \mathrm{~kg}$ ), 3 individual European perch Perca fluviatilis with total biomass of $0.5 \mathrm{~kg}$ (average fish weight $0.17 \mathrm{~kg}$ ), and 4 individual pike Esox lucius with total biomass of $3.4 \mathrm{~kg}$ (average fish weight $0.85 \mathrm{~kg}$ ) (Czech Anglers Union, unpubl. data).

\subsection{Sample collection and diet analysis}

The diet of Eurasian otter was investigated from spraints (otter faeces). Those spraints were collected on 11 December 2005 , and 14 January 2006. The whole stream $(11.7 \mathrm{~km})$ was searched by the same two experienced surveyors both times, carefully "zigzagging" along the banks while also searching mid-channel features (rocks, boulders, tree roots, and fallen branches). Only fresh or almost fresh new spraints with wet and soft consistency (Mason and Macdonald, 1987) were collected individually into plastic bags, sealed, labelled, and stored in a freezer $\left(-18^{\circ} \mathrm{C}\right)$. After being thawed, each spraint was soaked in a mixture of water and soapy detergent until the lumps lost their compactness. Remaining hard parts were washed through sieve (mesh size $0.5 \mathrm{~mm}$ ) several times to remove any remaining contaminants or detergent, then dried at room temperature. All recognizable remains (fish diagnostic bones, fish scales, non-fish parts) were separated and analysed under a stereo microscope (magnification 8-16×). Fish species were identified to the lowest possible taxonomic level based on morphological differences of diagnostic bones (os pharyngeum, maxillare, dentale, intermaxillare, operculare, praeoperculare, praevomer). The diagnostic bones were measured to the nearest $0.1 \mathrm{~mm}$ and paired whenever possible. The number of individuals represented in a spraint was determined by the highest total of any identifiable parts present after pairing. Our own collection of diagnostic bones was used to determine original size of damaged bones. Estimated original fish length $\left(L_{\mathrm{T}}\right.$, longitudo totalis in $\mathrm{cm}$ ) was calculated from the length of diagnostic bones using length-length equations from the work of Čech et al. (2008), Čech and Vejř́ik (2011), Čech and Čech (2013). Estimated original fish weight was calculated from the $\left(L_{\mathrm{T}}\right)$ using length-weight equations from the same sources. Amphibians were identified by examination of skeletal parts (maxillare and tibiofibula). Remains of chitinous external skeletons were used to identify crayfish. The number of amphibian and crayfish individuals in a spraint was determined by the highest number of identifiable parts present after pairing. Total weight of amphibians and crayfish was estimated using average weight of individuals previously caught on Chotýšanka stream (43g for frog Rana spp. and $51 \mathrm{~g}$ for crayfish Astacus fluviatilis). For frequency of occurrence calculation, each identified prey item was, after pairing, considered as one occurrence. Otter diet was expressed as $\%$ Frequency of Occurrence $(\% \mathrm{FO})$ following this method: $\%$ $\mathrm{FO}=$ the number of spraints with occurrence of certain prey item, divided by the total number of spraints examined, multiplied by 100 .

\subsection{Statistical analysis}

A statistical programme $\mathrm{R}$ ( $\mathrm{R}$ version 3.2.5, $\mathrm{R}$ Development Core Team, 2016) was used for statistical analyses. Shapiro-Wilk test was used to test the distribution of estimated fish lengths and weights in otter diet. Pearson's chi-square test was used to test the difference in proportion of fish species in the diet (contingency table $1 \times 12$ ), and to test the difference in proportion of fish species in catches of anglers and in the diet of otters (contingency table $2 \times 12$ ), using relative frequency of fish species. A 95\% confidence interval for frequency and estimated biomass of each individual species in otter diet was calculated using bootstrap analysis (based on content of individual spraints), comparing 1000 bootstrap samples, generated by $\mathrm{R}$ programme. Overlap between otter diet and catches of anglers was calculated using Pianka's index (range 0-1; Pianka and Pianka, 1976, Cupples et al., 2011), comparing relative frequency and estimated biomass of fish species in otter diet to relative frequency and estimated biomass of fish species in overall catches of anglers, respectively. Minimum probability level of $p<0.05$ was accepted for all the statistics, and all $p$-values are two-tailed.

\section{Results}

During winter 2005/2006, 279 otter spraints were found exclusively on kilometres (3.0-5.5) and (7.5-11.7) of the stream (Fig. 1, Table 2). Those spraints included 2731 diagnostic elements which gave 1532 individual fish, 54 frogs, and 9 crayfish after pairing.

Fish dominated otter diet in this area $(85 \%$ of estimated biomass). The overall fish diet of otter was composed of 12 fish species belonging to 5 families (Table 3). Gudgeon Gobio 
Table 3. Overall diet of Eurasian otter Lutra lutra on Chotýšanka stream (Chotýšanka 1, fishery no. 413 006) in winter 2005/2006: $n$, total number of individuals identified in the spraints; \%n, percentage of frequency; $95 \%$ CI $(\% n), 95 \%$ confidence interval on percentage by frequency; $b$ [g], estimated biomass identified in the spraints [g]; \% $b$, percentage of estimated biomass; $95 \%$ CI $(\% b), 95 \%$ confidence interval on percentage by estimated biomass; $\%$ FO, frequency of prey occurrence; $L$ mean, mean fish length $[\mathrm{cm}] ; L$ min-max, minimum-maximum fish length $[\mathrm{cm}] ; W$ mean, mean fish weight $[\mathrm{g}] ; W$ min-max, minimum-maximum fish weight $[\mathrm{g}]$; N/A, data not available.

\begin{tabular}{|c|c|c|c|c|c|c|c|c|c|c|c|}
\hline Species & $n$ & $\% n$ & $\begin{array}{l}95 \% \text { CI } \\
(\% n)\end{array}$ & $b[\mathrm{~g}]$ & $\% b$ & $\begin{array}{l}95 \% \text { CI } \\
(\% b)\end{array}$ & $\% \mathrm{FO}$ & $\begin{array}{l}L \\
\text { mean }\end{array}$ & $\begin{array}{l}L \\
\min -\max \end{array}$ & $\begin{array}{l}W \\
\text { mean }\end{array}$ & $\begin{array}{l}W \\
\min -\max \end{array}$ \\
\hline \multicolumn{12}{|l|}{ Cyprinidae } \\
\hline Common carp (Cyprinus carpio) & 14 & 0.9 & $0.7-1.1$ & 2926 & 15.7 & $5.1-26.7$ & 5.0 & 16.9 & $5.5-45$ & 209.0 & $2.4-1736$ \\
\hline Common dace (Leuciscus leuciscus) & 2 & 0.1 & $0.0-0.1$ & 10 & 0.1 & $0.0-0.1$ & 0.7 & 8.6 & $8.4-9$ & 4.9 & $4.5-5.4$ \\
\hline European chub (Squalius cephalus) & 95 & 6.0 & $4.8-7.4$ & 2508 & 13.4 & $12.3-14.5$ & 23.8 & 10.9 & $2.9-30$ & 26.4 & $0.2-250$ \\
\hline Roach (Rutilus rutilus) & 12 & 0.8 & $0.5-0.9$ & 378 & 2.0 & $1.8-2.6$ & 4.3 & 12.5 & $7.1-28$ & 31.5 & $3.3-210$ \\
\hline Stone moroko (Pseudorasbora parva) & 14 & 0.9 & $0.4-1.3$ & 22 & 0.1 & $0.1-0.1$ & 5.0 & 6.2 & $5.0-8$ & 1.6 & $0.8-2.3$ \\
\hline \multicolumn{12}{|l|}{ Salmonidae } \\
\hline Brown trout (Salmo trutta m. fario) & 27 & 1.7 & $1.3-2.1$ & 415 & 2.2 & $1.7-2.8$ & 9.7 & 12.2 & $8.6-18$ & 15.4 & $4.6-45.7$ \\
\hline Rainbow trout (Oncorhynchus mykiss) & 7 & 0.4 & $0.2-0.7$ & 2082 & 11.1 & $4.8-17.5$ & 2.5 & 33.1 & $32-34$ & 297.0 & $250-323$ \\
\hline \multicolumn{12}{|l|}{ Cottidae } \\
\hline Bullhead (Cottus gobio) & 3 & 0.2 & $0.0-0.4$ & 15 & 0.1 & $0.0-0.2$ & 1.1 & 7.4 & $6.9-8$ & 4.9 & $3.8-6.5$ \\
\hline \multicolumn{12}{|l|}{ Non-fish } \\
\hline Frogs (Rana spp.) & 54 & 3.4 & $2.8-4.1$ & 2322 & 9.6 & $8.0-11.0$ & 14.9 & N/A & N/A & 43.0 & N/A \\
\hline Crayfish (Astacus fluviatilis) & 9 & 0.6 & $0.2-1.0$ & 459 & 2.5 & $0.1-4.3$ & 3.2 & N/A & N/A & 51.0 & N/A \\
\hline Total & 1595 & 100.0 & - & 18695 & 100.0 & - & - & 8.4 & $2.9-45$ & 10.4 & $0.2-1736$ \\
\hline
\end{tabular}

gobio was the most commonly consumed species. The most important fish families were cyprinids (Cyprinidae), followed by salmonids (Salmonidae) and percids (Percidae). Majority of fish eaten were smaller than $10 \mathrm{~cm}$ and lighter than $10 \mathrm{~g}(78.5 \%$ and $79.4 \%$, respectively; Figs. 2 and 3). Fish of medium or high angling value made up $10 \%$ in overall otter diet by frequency of fish species and $45 \%$ by estimated biomass of fish species (Table 4). Otters consumed fish with average length of $8.4 \mathrm{~cm}$ (95\% confidence interval: $8.2-8.6)$ and average weight of $10.4 \mathrm{~g}$ (95\% confidence interval: 7.7-13.1).

Non-fish prey consisted of native frogs Rana spp. and native crayfish $A$. fluviatilis.

Shapiro-Wilk test showed that neither the length nor the weight of fish consumed by otters have normal distribution; for length $(W=0.80, p<0.001)$ and for weight $(W=0.11$, $p<0.001)$. Gudgeon was consumed at disproportionally higher rate than other species by frequency (chi-squared= 1915.3, d.f. $=11, p<0.001)$.

Anglers took different fish species in years 2005-2006 than otters did during winter 2005/2006 by frequency (chisquared $=191.31$, d.f. $=11, p<0.001$ ). Anglers took fish with average weight of $290 \mathrm{~g}$; otters took fish with average weight of $10.4 \mathrm{~g}$. In otter diet, brown trout $S$. trutta m. fario made up $1.7 \%$ by frequency (95\% confidence interval: $1.3-2.1 \%)$ and $2.2 \%$ by estimated biomass (95\% confidence interval: $1.7-$ $2.8 \%$ ), and rainbow trout $O$. mykiss made up $0.4 \%$ by

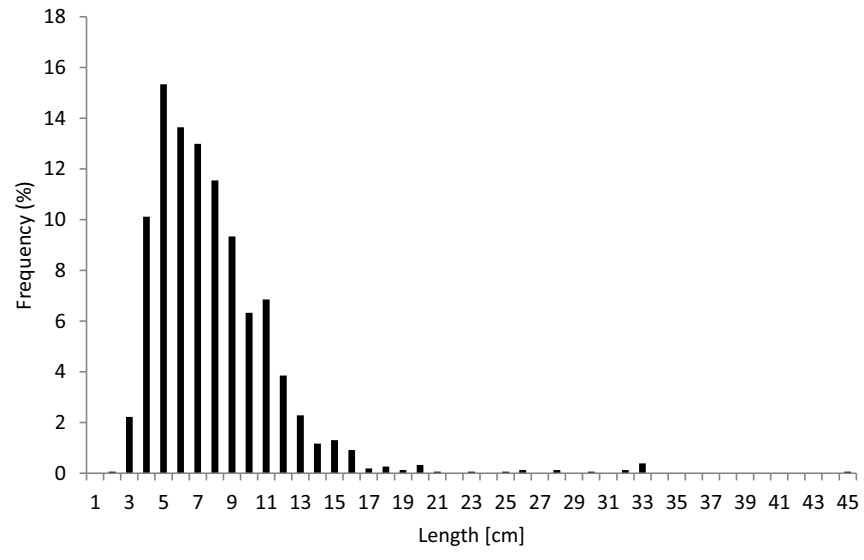

Fig. 2. Frequency distribution of estimated length $\left(L_{\mathrm{T}}\right)$ of all fish $(n=1532)$ consumed by Eurasian otter Lutra lutra on Chotýšanka stream in winter 2005/2006.

frequency ( $95 \%$ confidence interval: $0.2-0.7 \%$ ) and $11.1 \%$ by estimated biomass (95\% confidence interval $4.8-17.5 \%)$. Dietary overlap between otter diet and catches of anglers was low $(I=0.07)$ for frequency of fish species and moderate $(I=0.30)$ for estimated biomass of fish species. 


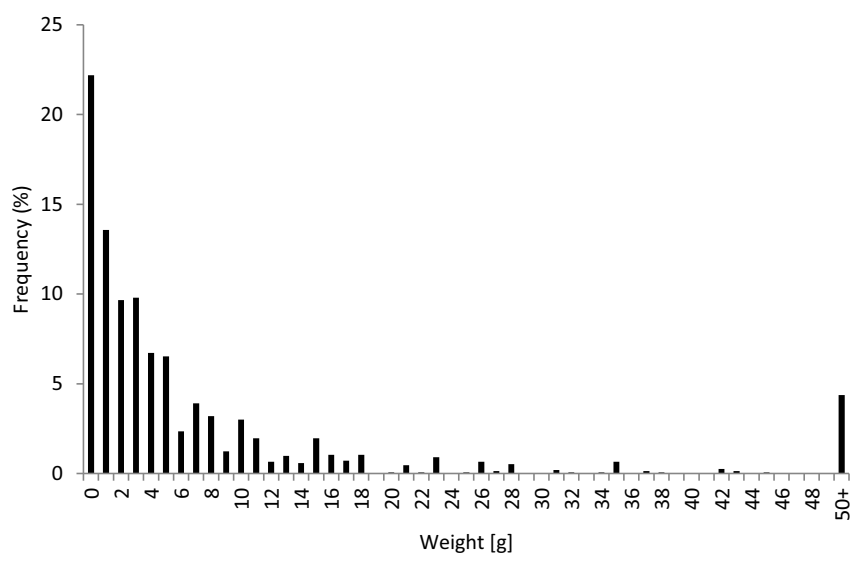

Fig. 3. Frequency distribution of estimated weight of all fish $(n=1532)$ consumed by Eurasian otter Lutra lutra on Chotýšanka stream in winter $2005 / 2006$. $X$-axis: the value 0 represents fish with weight under $0.5 \mathrm{~g}$; the value $50+$ represents fish with weight $50 \mathrm{~g}$ and more.

Table 4. Overall fish diet of Eurasian otter Lutra lutra on Chotýšanka stream (Chotýšanka 1, fishery no. 413 006) in winter 2005/2006: value, the value of fish species to anglers (high - salmonids, common carp Cyprinus carpio; medium - European chub Squalius cephalus, European perch Perca fluviatilis; none - other fish species included in Table 3); $\% n$, percentage of frequency; $\% b$, percentage of estimated biomass.

\begin{tabular}{lcc}
\hline Value & $\% n$ & $\% b$ \\
\hline High & 3 & 29 \\
Medium & 7 & 16 \\
None & 86 & 40 \\
\hline
\end{tabular}

\section{Discussion}

Winter diet of otter on Chotýšanka stream was dominated by fish. That is common for otters, regardless of habitat type (Erlinge, 1969; Kruuk and Moorhouse, 1990; Carss, 1995; Jedrzejewska et al., 2001; Kruuk, 2006; Lanszki and Sallai, 2006; Krawczyk et al., 2016). Amphibians and crayfish are the most important non-fish prey in temperate areas (Jedrzejewska et al., 2001; Chanin, 2003). Lower number of fish species in otter diet is common for smaller rivers and streams, especially in comparison to coastal areas or areas with combination of ponds and/or rivers and/or streams (Harna, 1993; Gourvelou et al., 2000; Marques et al., 2007; Kortan et al., 2010). It is mainly caused by lower species diversity in the environment (Jedrzejewska et al., 2001). On Chotýšanka, the upstream pond was fenced and guarded by German Shepherd dogs, which disallows otters to diversify their diet by hunting pond fish (Britton et al., 2005), although some cyprinids and percids could penetrate into the stream from the pond through its outlet.
Gudgeon G. gobio was the dominant prey item in otter diet in this area. Otters somewhat prefer smaller fish that they can consume directly in the water (Roche et al., 1995; Jurajda et al., 1996; Lanszki et al., 2015), which makes gudgeon an optimal prey, as it is both small-growing and very abundant in this area (Czech Anglers Union, unpubl. data). Majority of fish consumed by otters are small (Kruuk et al., 1993), especially on small streams with a lack of larger fish (Lanszki et al., 2009; Kortan et al., 2010; Almeida et al., 2012). Exceptions for this rule do exist (Carss et al., 1990), especially within pond complexes stocked with larger fish (Adámek et al., 2003; Britton et al., 2005; Kortan et al., 2007; Almeida et al., 2012).

One large carp (1736 g, identified from large scales) was found in otter diet. With average daily food intake being 0.75 $1.5 \mathrm{~kg}$ per adult otter (Kruuk, 1995), otters sometimes catch larger fish that they cannot consume completely (Adámek et al., 2003; Kortan et al., 2007; Lanszki et al., 2015). Unlike fish-eating birds (e.g. the Great cormorant Phalacrocorax carbo), otters do not have to swallow their prey whole. They can use teeth and claws to tear the prey to smaller pieces and bite out only the soft tissue, allowing them to prey upon larger fish. Head parts of larger fish are sometimes not consumed, so diagnostic bones of those fish can be missing in the spraint, leading to underestimation of larger fish in the diet. This is mainly true for fish with higher weight than the daily food intake of otter; those are mostly being exploited at times of food shortage (Kortan et al., 2007). Stocked rainbow trout consumed by otters weighted $200-400 \mathrm{~g}$, which is less than the daily food intake of otter, so those should be consumed whole.

Otters consumed less salmonid than what is expected on trout streams, especially considering the fish stocking (Carss et al., 1990; Kožená et al., 1992; Harna, 1993; Ludwig et al., 2002; Jacobsen, 2005; Kortan et al., 2010). On Chotýšanka stream, the goal of brown trout $S$. trutta m. fario stocking is to establish a prospering population in the stream (Czech Anglers Union, pers. comm.). Rainbow trout $O$. mykiss is being stocked for angling purposes only, being the main target for anglers. Only brown trout with size $9-18 \mathrm{~cm}$ and rainbow trout with size $32-34 \mathrm{~cm}$ were identified in otter diet, which corresponds well with the size of stocked trout. Otters did not catch any trout outside of the stocked size. Otters could be prioritizing stocked trout in winter (Ludwig et al., 2002; Jacobsen, 2005), mostly because fish stocking usually occurs in autumn, lower water temperature favours endothermic predator over its ectothermic prey, and anti-predator behaviour is poorly developed in hatchery-reared fish (Maynard et al., 1995). In warmer months, otters could be partially ignoring salmonids, mostly because those are faster swimmers than cyprinids (Erlinge, 1968). Salmonids are being taken from fish farms more than from trout streams (Ludwig et al., 2002). Stocked salmonids are being preferably taken on streams with existing salmonid populations (Jacobsen, 2005). For otters, availability of salmonids may be more important than salmonid abundance. Otters frequently prey upon adult migrating Atlantic salmon Salmo salar (Carss et al., 1990; Kortan et al., 2010) and juvenile salmon and trout (Kruuk et al., 1993). Mink Mustela vison was found responsible for increased mortality of salmon and trout parr in small Norwegian streams (Heggenes and Borgstrom, 1988).

Otters took different fish species of different sizes than anglers did. While otters were mostly interested in small- 
growing fish species with medium or no angling value, anglers were mainly interested in salmonids, European chub $S$. cephalus, and other large-growing species. The dietary overlap index was significantly different when calculated and compared for frequency of fish species and for estimated biomass of fish species. Dietary overlap was low for frequency, but moderate for estimated biomass. Otters took very different fish species than anglers by frequency, but the difference was lower for estimated biomass. Similarly, otters seemed to feed mostly on fish of no angling value by frequency, but the amount of fish of medium and high angling value was higher for estimated biomass. Anglers took bigger fish than otters did, mostly because only salmonids bigger than $25 \mathrm{~cm} L_{\mathrm{T}}$ can be legally taken. European chub can be taken at all sizes on trout streams, but anglers took mostly larger individuals. Accidental catches of undersized fish are not recorded by anglers; those fish are returned to the stream after being caught. All rainbow trout consumed by otters were of catchable size for anglers $\left(>25 \mathrm{~cm} L_{\mathrm{T}}\right)$; all brown trout consumed by otters were undersized for anglers $\left(<25 \mathrm{~cm} L_{\mathrm{T}}\right)$. On streams and rivers, otters were observed to prey upon economically unimportant fish species (Lanszki and Sallai, 2006). The differences in catches of fish between fishermen and otters are usually lower within pond systems with high concentration of stocked fish like common carp C. carpio or other largegrowing species with high commercial value (Adámek et al., 2003; Kortan et al., 2007; Marques et al., 2007). Fish in small water basins with no hideouts are especially vulnerable to otter predation (e.g. Kortan et al., 2007), but even in these conditions, otters still avoid fish heavier than $1 \mathrm{~kg}$ (Lanszki et al., 2001).

\section{Conclusion}

Otters took different fish species of different sizes than anglers did. Otters preyed mostly upon small-growing species of medium or no value to anglers, although stocked and highly valued salmonids were consumed as well. Anglers took a low variety of large-growing fish species of medium or high angling value. Therefore, the difference in catches of fish between otters and anglers was high. We studied the difference in catches of fish during one winter season on one lowland stream with salmonid stocking and a limited number of otters inhabiting the area (one to three otters). In order to better understand the differences in catches of fish between anglers and otters on a larger scale, more studies need to be performed on streams, rivers, and lakes where fish stocking is a common practice. We suggest that a study should be carried out, comparing more different freshwater habitats with stocking of different fish species from different families (e.g. salmonids, cyprinids, esocids, and percids) in different geographical areas for a longer time period.

Acknowledgements. We thank P. Čech for help in the field, Dr. J. Poupě, P. Horáček, J. Frišová, and the Czech Anglers Union for providing data, Prof. P. Kindlman, Assoc. Prof. J. Matěna, J. Jančařík, M. Sekera, and Assoc. Prof. M. Omelka for discussion regarding our methodological procedure, and Prof. M. Morris for careful reading and correcting the English. The study was supported by UNCE (institutional resources of Ministry of Education, Youth and Sports of the Czech Republic for the support of science and research).

\section{References}

Aarestrup K, Jepsen N, Koed A, Pedersen S. 2005. Movement and mortality of stocked brown trout in a stream. J Fish Biol 66: 721728.

Adámek Z, Kortan D, Lepic P, Andreji J. 2003. Impacts of otter (Lutra lutra) predation on fish ponds: a study of fish remains at ponds in the Czech Republic. Aquacult Int 11: 389-396.

Almeida D, Gordon CH, Masson L, Miranda R, Murai M, Sayer CD. 2012. Changes in the diet of recovering Eurasian otter population between the 1970s and 2010. Aquat Conserv Mar Freshw Ecosys 22: 26-35.

Bachman RA. 1984. Foraging behaviour of free-ranging wild and hatchery brown trout in a stream. Trans Am Fish Soc 113: 1-32.

Baer J, Blasel K, Diekmann M. 2007. Benefits of repeated stocking with adult, hatchery-reared brown trout, Salmo trutta, to recreational fisheries? Fish Manag Ecol 14: 51-59.

Blanco-Garrido F, Prenda J, Narvaéz M. 2008. Eurasian otter (Lutra lutra) diet and prey selection in Mediterranean streams invaded by centrarchid fishes. Biol Invasions 10: 641-648.

Britton JR, Shepherd JS, Toms S, Simpson V. 2005. Presence of carp, Cyprinus carpio, in the diet of the otter, Lutra lutra. Fish Manag Ecol 12: 221-223.

Carss DN. 1995. Foraging behaviour and feeding ecology of the otter Lutra lutra: a selective review. Hystrix 7: 179-194.

Carss DN, Kruuk H, Conroy JWH. 1990. Predation on adult Atlantic salmon Salmo-salar (L.), by otters, Lutra lutra (L.), within the River Dee system, Aberdeenshire, Scotland. J Fish Biol 37: 935-944.

Čech M, Čech P. 2013. The role of floods in the lives of fish-eating birds: predator loss or benefit? Hydrobiologia 717: 203-211.

Čech M, Vejř́ik L. 2011. Winter diet of great cormorant (Phalacrocorax carbo) on the River Vltava: estimate of size and species composition and potential for fish stock losses. Folia Zool 60: 129-142.

Čech M, Čech P, Kubečka J, Prchalová M, Draštík V. 2008. Size selectivity in summer and winter diets of great cormorant (Phalacrocorax carbo): does it reflect season-dependent difference in foraging efficiency? Waterbirds 31: 438-447.

Chanin PRF. 2003. Ecology of European otter. Conserving Natura 2000. Rivers Ecology Series 10. Peterborough, UK: English Nature.

Conroy JWH, Chanin PRF. 2002. The status of the Eurasian otter (Lutra lutra). IUCN OSG Bulletin 19A, pp. 24-48.

Copp GH, Roche K. 2003. Range and diet of Eurasian otters Lutra lutra (L.) in the catchment of the River Lee (South-east England) since reintroduction. Aquat Conserv Mar Freshw Ecosys 13: 65-76.

Cupples JB, Crowther MS, Story G, Letnic M. 2011. Dietary overlap and prey selectivity among sympatric carnivores: could dingoes suppress foxes through competition of prey? J Mamm 92: 590-600.

Erlinge S. 1968. Food studies on captive otters Lutra lutra L. Oikos 19: $259-270$

Erlinge S. 1969. Food habits of otter Lutra lutra L. and mink Mustela vison Schreber in a trout water in southern Sweden. Oikos 20: 1-7.

Geidezis LC. 2002. Diet of otters (Lutra lutra) in relation to prey availability in a fish pond area in Germany. IUCN OSG Bulletin 19A, pp. 72-76.

Gourvelou E, Papageorgiou N, Neophytou C. 2000. Diet of the otter Lutra lutra in Lake Kerkini and stream Milli-Aggistro, Greece. Acta Theriol 45: 35-44.

Harna G. 1993. Diet composition of the otter Lutra lutra in the Bieszczady Mountains, south-east Poland. Acta Theriol 38: $167-$ 174. 
Heggenes J, Borgstrom R. 1988. Effect of Mink, Mustela vison Schreber, predation on cohorts of juvenile Atlantic salmon, Salmo salar L., and brown trout, S. trutta L., in three small streams. J Fish Biol 33: 885-894.

Jacobsen L. 2005. Otter (Lutra lutra) predation on stocked brown trout (Salmo trutta) in two Danish lowland rivers. Ecol Freshw Fish 14: 59-68.

Jedrzejewska B, Sidorovich VE, Pikulik MM, Jedrzejewski W. 2001. Feeding habits of the otter and the American mink in Bialowieza Primeval Forest (Poland) compared to other Eurasian populations. Ecography 24: 165-180.

Juhász K, Balázs AL, Perpék M, Nagy SA, Végvári Z. 2013. Effects of extensive fishpond management and human disturbance factors on Eurasian otter (Lutra lutra L 1958) populations in Eastern Europe. North-West J Zool 9: 227-238.

Jurajda P, Prasek V, Roche K. 1996. The autumnal diet of otter (Lutra lutra) inhabiting four streams in the Czech Republic. Folia Zool 45: 9-16.

Kloskowski J. 2000. Selective predation of otters Lutra lutra on common carp Cyprinus carpio at farmed fisheries. Mammalia 64: 287-294.

Kortan D, Adámek Z, Poláková S. 2007. Winter predation by otter, Lutra lutra, on carp pond systems in South Bohemia (Czech Republic). Folia Zool 56: 416-428.

Kortan D, Adámek Z, Vrána P. 2010. Otter, Lutra lutra, feeding pattern in the Kamenice River (Czech Republic) with newly established Atlantic salmon, Salmo salar, population. Folia Zool 59: 223-230.

Kožená I, Urban P, Štouračová I, Mazur I. 1992. The diet of the otter (Lutra lutra Linn.) in the Polana protected landscape region. Folia Zool 2: 107-122.

Kranz A. 2000. Otters (Lutra lutra) increasing in Central Europe: from the threat of extinction to locally perceived overpopulation? Mammalia 64: 357-368.

Krawczyk AJ, Bogdziewicz M, Majkowska K, Glazaczow A. 2016. Diet composition of the Eurasian otter Lutra lutra in different freshwater habitats of temperate Europe: a review and metaanalysis. Mamm Rev 46: 106-113.

Kruuk H. 1995. Wild otters: predation and populations. Great Britain: Oxford University Press.

Kruuk H. 2006. Otters: ecology, behaviour and conservation. Great Britain: Oxford University Press.

Kruuk H, Moorhouse A. 1990. Seasonal and spatial differences in food selection by otters (Lutra lutra) in Shetland. J Zool 221: 621637.

Kruuk H, Conroy JWH, Moorhouse A. 1991. Recruitment to a populations of otters (Lutra lutra) in Shetland, in relation to fish abundance. J Appl Ecol 28: 95-101.

Kruuk H, Carss DN, Conroy JWH, Durbin L. 1993. Otter Lutra lutra (L.) numbers and fish productivity in rivers in northeast Scotland. Symp Zool Soc Lond 65: 171-191.

Lanszki J, Sallai Z. 2006. Comparison of the feeding habits of Eurasian otters on a fast flowing river and its backwater habitats. Mamm Biol 6: 336-346.
Lanszki J, Széles GL. 2006. Feeding habits of otters living on three moors in the Pannonian ecoregion (Hungary). Folia Zool 55: 358366.

Lanszki J, Kormendi S, Hancz S, Martin TG. 2001. Examination of some factors affecting selection of fish prey by otters (Lutra lutra) living by eutrophic ponds. J Zool 255: 97-103.

Lanszki J, Széles GL, Yoxon G. 2009. Diet composition of otters (Lutra lutra L.) living on small watercourses in southwestern Hungary. Acta Zool Acad Sci Hung 55: 293-306.

Lanszki J, Bauer-Haaz EA, Szeles GL, Heltai M. 2015. Diet and feeding habits of the Eurasian otter (Lutra lutra): experiences from post mortem analysis. Mamm Study 40: 1-9.

Larsen K. 1972. New trends in planting trout in lowland streams. The results of some controlled Danish liberations. Aquaculture 1: 137171.

Ludwig XG, Hokka V, Sulkava R, Ylonen H. 2002. Otter Lutra lutra predation on farmed and free-living salmonids in boreal freshwater habitats. Wildlife Biol 8: 193-199.

Marques C, Rosalino LM, Santos-Reis M. 2007. Otter predation in a trout fish farm of central-east Portugal: preference for 'fast-food'? River Res Appl 23: 1147-1153.

Mason CF, Macdonald SM. 1986. Otters: ecology and conservation. New York: Cambridge University Press.

Mason CF, Macdonald SM. 1987. The use of spraints for surveying otter Lutra lutra populations: an evaluation. Biol Conserv 41: 167177.

Maynard DJ, Flagg TA, Mahnken CVW. 1995. A review of seminatural culture strategies for enhancing the postrelease survival of anadromous salmonids. Am Fish Soc Symp 15: 307-314.

Miranda R, Gordon CH, Williams J, Beyer K, Rodolphe GE. 2008. Do Eurasian otters Lutra lutra (L.) in the Somerset Levels prey preferentially on non-native fish species? Fundam Appl Limnol 172: 339-347.

Naslund I. 1992. Trout in running waters: a review of habitat requirements, density dependent factors and stockings. Inf Fran Sotvattens-Lab 3: 43-82.

Pianka ER, Pianka HD. 1976. Comparative ecology of twelve species of nocturnal lizards (Gekkonidae) in the Western Australian desert. Copeia 1: 125-142.

Rasmussen G, Geertz-Hansen P. 1998. Stocking of fish in the Denmark. In: Cowx I, ed. Stocking and introduction of fish. Oxford: Fishing News Books.

Roche K, Harris R, Warrington S, Copp GH. 1995. Home range and diet of re-introduced European otters Lutra lutra (L.) in Hertfordshire rivers. Aquat Conserv Mar Freshw Ecosys 5: 87-96.

Sittenthaler M, Bayer H, Unfer G, Kuehn R, Parz-Gollner R. 2015. Impact of fish stocking on Eurasian otter (Lutra lutra) densities: a case study on two salmonid streams. Mamm Biol 80: 106-113.

Taastrom H, Jacobsen L. 1999. The diet of otters (Lutra lutra L.) in Danish freshwater habitats: comparisons of fish prey populations. J Zool 248: 1-13.

Václavíková M, Václavík T, Kostkan V. 2011. Otters vs. fishermen: Stakeholders' perceptions of otter predation and damage compensation in the Czech Republic. J Nat Conserv 19: 95-102.

Cite this article as: Lyach R, Čech M. 2017. Do otters target the same fish species and sizes as anglers? A case study from a lowland trout stream (Czech Republic). Aquat. Living Resour. 30: 11 